\title{
The 50-year history of the Korean Society of Plant Taxonomists: Professional manpower training and research activity
}

\author{
Nam Sook LEE* \\ Department of Life Science, Ewha Womans University, Seoul 03760, Korea \\ (Received 18 March 2018; Revised 11 May 2018; Accepted 26 December 2018)
}

\begin{abstract}
Since the establishment of the Korean Society of Plant Taxonomists (KSPT) on Dec. 13, 1968, the professional manpower training and research activities have been analyzed. The survey method was based on the homepage of the KSPT and the Korean J. Pl. Taxon, and on data provided by each university about professional manpower. Over the past 50 years, a total of 680 specialists in plant taxonomy have been trained, consisting of 537 master's degree holders (274 males, 263 females) from 30 universities and 143 Ph.D.s (97 males, 46 females) from 26 universities, and the number has increased significantly since 1998. With regard to changes in the field of research over the last ten years, revision papers were the most common in the period of 1988-1997 ( $72 \%$ ), but this rate has decreased to $51 \%$ over the last ten years, while the number of unrecorded papers has increased to $28 \%$. In the 629 revision papers on taxa, $49 \%$ of the taxa belong to Asteraceae, Ranunculaceae, Cyperaceae, Liliaceae, Rosaceae, Fabaceae, Apiaceae, Lamiaceae, Orchidaceae, Oleaceae, Euphorbiaceae, Polygonaceae, and Amaryllidaceae. With regard to changes in research methods, the number of morphological papers increased from $6 \%$ to $51 \%$, while pollen papers have decreased from a rate of $20 \%$ to only $2 \%$. Chromosome studies account for 3-4\%, chemotaxonomic studies $2 \%$, and DNA studies remain low at $3-16 \%$. The percentage of papers in English now stands at $43 \%$, mainly due to the increased number of papers on unrecorded species.
\end{abstract}

Keywords: 50-year history, the Korean Society of Plant Taxonomists, professional manpower, research activity

한국식물분류학회는 1968년 12월 13일에 이화여대 생 물학과가 있던 이학관(현 학생문화관)에서 창립총회를 가진 이래 창립 50 주년을 맞이하게 되었다. 우리나라 분 류학도들의 결속이 필요함을 통감하여 6명(박만규, 안학 수, 이덕봉, 이영노, 이우철, 정영호)이 발기하였다. 창립 시 박만규 회장과 이영노 부회장, 정태현 명예회장, 6 명의 이사, 및 간사인 이우철 교수와 오용자 교수를 포함하여 총 28명으로 출발하였다. 이러한 회원 수는 2018년 2월 현 재 494명(정회원 106 명과 일반회원 388 명)과 단체회원 36 명, 해외회원 및 단체 22 명으로 총 552 명이며 50 년 전과 비교 하여 약 20 배 증가하였다. 학회를 운영하는 임원진은 25 대에 걸쳐 이어지고 있으며, 1-2대 때에는 회장 1 명과 부 회장 1 명이었으나, 3 대부터 20대까지는 부회장 2명, 2009 년 21대부터 23대까지는 부회장 3명, 24대부터 현재의 25 대는 부회장이 4명으로 증가하였다. 이사도 창립 당시 6 명에서 현재 93명으로 크게 증가하였으며, 명예이사가 8
명이다. 학회는 일반학술단체로 45년간 운영하다가 2013 년 2월 사단법인으로 발족하여 창립총회를 개최하였다. 학회를 상징하는 로고는 1994년에 공보전을 통해 제정되 었으며, 우리나라 고유의 삼태극 문양 속에 식물분류학의 주 대상인 나자식물, 피자식물의 문양을 넣어 우리나라를 나타내면서 일반인이 이해하기 쉬운 것이 선정되었다. 이 로고는 학회 홈페이지와 과거의 뉴스레터에는 사용되고 있으나 학회지 표지나 일반인을 위한 공개강좌 수료증 및 최근 새로 발간된 뉴스레터에는 사용되고 있지 않다.

학회의 주요사업은 학회지 발간, 학술대회, 국제세미나 /국제심포지움 개최, 야외관찰회, 워크숍, 및 식물분류학 공개강좌이다.

학회의 학술적 위치를 나타내는 학회지는 창립 첫 해에 1호와 2호를 발간했으나, 1970년도부터 1977년까지는 1 호와 2호를 합병하여 발간했으며, 그 중 1974년과 1977년 에는 학회지를 발간조차 하지 못했다. 그러나 다시 1982

\footnotetext{
*Author for correspondence: namsook@ewha.ac.kr
} 
년과 1983년에는 다시 연간 2 개의 호를 발간하였고 1984 년부터 1986년까지는 3 개의 호를 발간하였다. 그리고 1987 년부터는 현재와 같이 매년 4 개의 호를 발간하고 있어 2017년 말까지 47권 총 150호를 발간하였다. '식물분류학 회지'의 제호는 갈물 이철경 선생이 쓴 것을 사용하고 있 으나 최근에는 영문 제호보다 글자 크기를 작게 하였다. 학 술대회는 매년 1회 개최하는 연례행사로 2003년부터 2009년까지는 한국생물과학협회에 가입하여 타 학술단 체들과의 공동 행사로 진행한 바 있으나 2010년부터 다시 원래의 단독 행사로 진행하고 있다. 야외관찰회는 창립 초기부터 1976년까지 8년 동안 매주 일요채집회를 개최 하였고, 그 후 1998년까지는 주로 연 2회, 1999년부터 현재 까지는 연 1 회 춘계야외관찰회를 개최하고 있다. 또한 워 크솝을 1993년부터 단독으로 실시하다가 2005년부터 야 외관찰회와 동시에 진행하고 있다. 일반인을 위한 사회교 육사업으로 사회교육위원장의 주도하에 연 7회 분류학 강 좌를 실시하여 6회 이상 수강자에 한해 매년 40-80명에게 수료증을 수여하고 있다. 학회의 소식을 알리는 뉴스레터 는 1992년에 시작되어 3년간 발간되고 중단되었으나, 2010년부터 발전위원장이 담당하여 다시 발간되고 있다.

이와 같이 지난 50 년 동안 학회 조직 및 구성원, 야외관 찰회, 국제학술회의, 사회교육 등 다양한 측면에서 학회 가 변화해 왔음을 알 수 있다. 본 기고에서는 이러한 변화 들 중 전문인력 양성과 학회지에 발표된 논문을 바탕으로 한 연구 활동의 변화를 분석하고 현황을 파악하여, 이를 바탕으로 학회의 미래를 준비하기 위한 기초자료를 마련 하고자 한다.

\section{조사 과정}

본 기고를 위해 전문인력 양성과 학회지 및 연구활동에 대하여 변화된 내용과 정도를 조사하였다. 조사를 위해 식물분류학회 홈페이지와 식물분류학회지에 나타난 자 료들을 이용하였고(Korean Journal of Plant Taxonomy, 1969-2017), 전문인력에 대해서는 각 대학에서 제공한 자 료를 바탕으로 분석하였다. 자료를 제공하지 않은 일부 기관의 경우 해당 홈페이지 등을 검색하여 포함시켰기 때 문에 일부 기관의 자료는 누락되었을 수 있다. 한국식물 분류학회의 50 년사를 뒤돌아보는 의미에서 국내 기관의 국내 식물분류학자들에 의해 양성된 국내 학위 소지자에 국한하여 조사하였다. 50년간 발표된 학회지 논문 1,010 편에 나타난 연구분야는 미기록종(종, 아종, 변종, 귀화종 포함), 식물상, 분류군 검토, 고유종, 신종(신아종, 신변종 포함) 및 기타(소고, 외국인채집관련, 표본실, 학명, 고식 생, 국가식물표준목록, 고교 교과서, 근대식물분류학사, 자연사박물관의 국제협력 등)으로 구분하였다. 발표된 논 문의 연구방법은 형태(미세 형태, 해부 포함)와 기재, 염색 체, 화분, 성분, 유전자와 기타(목록, 개요, 분포 등)로 구분 하였다. 전문인력 자료와 학술활동 자료는 엑셀파일로 정
리하여 표와 막대그래프 및 파이그래프로 나타내었다. 분 석 주기는 학회 50 주년을 10 년 단위로 구분하여 창립한 1969년(단, 전문인력은 1957년)-1977년, 1978-1987년, 1988-1997년, 1998-2007년, 2008-2017년(단, 석박사는 2018 년 2월까지)으로 구분하여 변화의 추이를 분석하였다.

\section{전문인력양성}

식물분류학회를 창립한 이래 각 기관에서 양성된 식물 분류학을 전공한 전문인력은 총 680명(2018년 2월말 기 준)으로, 석사는 30 개 대학에서 약 537 명, 박사는 26 개 대 학에서 143명이 배출되었으며, 남성 371명, 여성 309명 이다(Table 1). 1957-1977년에 석사와 박사의 총 수는 21 명(남성 14명, 여성 7명)이었다. 이후 1978-1987년에 62 명(남성 34명, 여성 28명), 1988-1997년에 102명(남성 64명, 여성 38명), 1998-2007년에 209명(남성 102명, 여성 107명), 2008-2017년에 286명(남성 157명, 여성 129명)으로 크게 증가하였다(Fig. 1). 이 중 석사는 총 537명으로 남성 274명, 여성은 263명이다. 1957-1977년의 석사 수는 19명(남성 13 명, 여성 6명)이다. 이후 1978-1987년에 51명(남성 27명, 여성 24명), 1988-1997년에 87명(남성 51명, 여성 36명), 1998-2007년에 180명(남성 84명, 여성 96명), 2008-2017년 에는 200명(남성 99명, 여성 101명)으로 여성이 특히 크게 증가하였다(Fig. 2A). 식물분류학 박사의 총 수는 143명(남 성 97명, 여성 46명)이다. 1969-1977년에 2명(남성 1명, 여성

Table 1. The number of Masters, Ph.D.s and the training institutions in plant taxonomy.

\begin{tabular}{lcccccccc}
\hline \hline & \multicolumn{3}{c}{ Masters } & & \multicolumn{3}{c}{ Ph.D.s } \\
\cline { 2 - 3 } \cline { 7 - 9 } \cline { 7 - 9 } & Total & Male Female & & Total & Male Female \\
\hline Training institution & 30 & & & & 27 & & \\
Master of Science & 476 & 235 & 241 & & 131 & 89 & 43 \\
Master of Agriculture & 39 & 23 & 16 & & 11 & 8 & 3 \\
Master of Education & 22 & 16 & 6 & & - & - & - \\
Total & 537 & 274 & 263 & & 143 & 97 & 46 \\
\hline
\end{tabular}

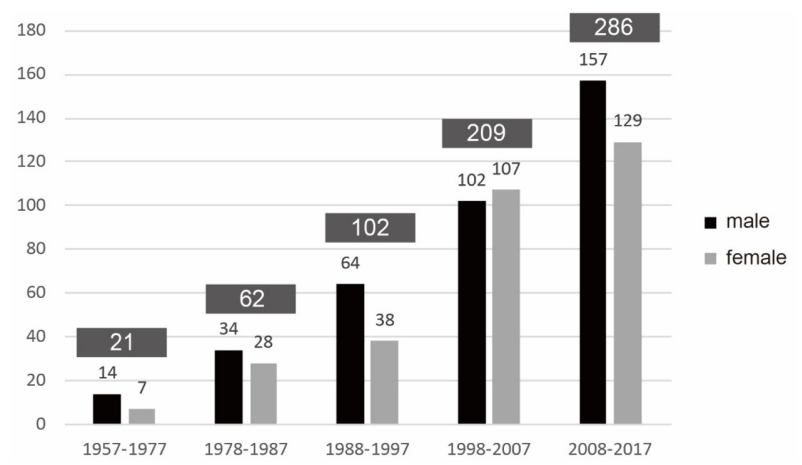

Fig. 1. Change in the total number of masters and Ph.D.s in decade increments. 
1명), 1978-1987년에 11명(남성 7명, 여성 4명), 1988-1997년 에 15명(남성 13명, 여성 2명), 1998-2007년에 29명(남성 18명, 여성 11명) 및 2008-2017년에 86명 (남성 58명, 여성 28명)으로 크게 증가하였다(Fig. 2B). 특히 1998년부터 최

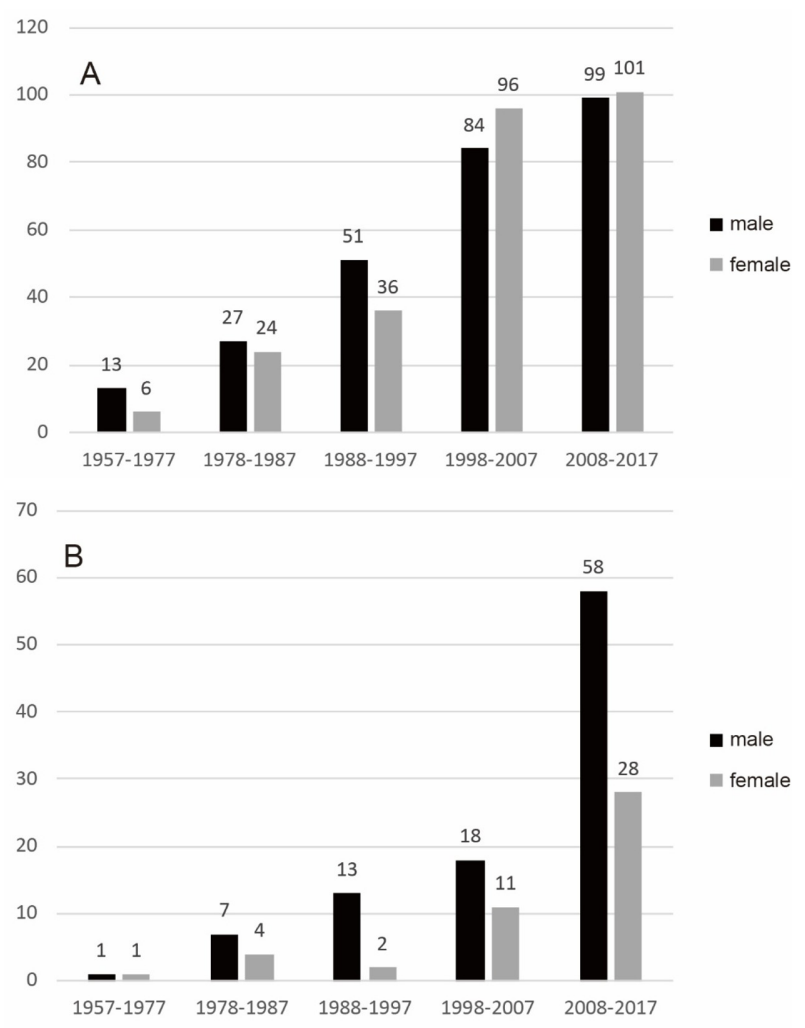

Fig. 2. Change in the number of Masters (A) and Ph.D.s (B) in decade increments.
근 20년간 석박사 수가 크게 증가한 배경은 우리나라의 생물다양성협약 가입(1994년), 1987년에 조성된 광릉수목 원이 국립수목원으로 승격(1999년)하고, 국립생물자원관 (2002년 기본계획 설립, 2007년 개관), 국립생태원(2007년 설립 협약, 2013년 개관), 국립낙동강생물자원관(2016년 개관) 및 국립백두대간수목원(2017년 개관) 등에 필요한 인력과 관련된 것으로 판단된다. 또한 여성의 석박사 수 가 크게 증가하였는데, 특히 여성 석사의 경우는 남성의 수와 거의 비슷할 정도로 크게 증가하였다. 그러나 여성 석사에서 여성 박사로의 진학률은 남성에 비해 크게 낮았 다. 즉, 남성 석사에 대한 박사의 비율이 약 $35 \%$ 인데 반해 여성 석사에 대한 박사의 비율은 약 $18 \%$ 로 낮았다. 결과 적으로 여성박사의 수(46명)는 남성박사의 수(97명)의 약 $47 \%$ 에 해당한다. 전반적으로 최근 20 년 동안 여성 석박사 수의 증가는 사회적으로 양성평등 의식이 개선된 것과 관 련된 것으로 여겨진다. 즉, 여성주간의 지정(1996년), 남녀 평등상 운영(1999년), 여성부 설립(2001년), (재)한국양성 평등교육진흥원(2003년), 대중매체의 성차별 개선 등의 사 회적 영향과 무관하지 않은 것으로 가늠된다. 그러나 여성 석사에서 박사로의 진학률이 남성에 비해 크게 낮은 것은 사회적으로 양성평등 의식이 개선되었어도 출산과 육아 및 여성채용에 대한 사회적 인식과도 관련이 있을 것으로 사료된다. 전문인력 배출기관은 30 개 대학으로 그 중 20 개 기관만을 나타내었다(Fig. 3). 식물분류학연구자가 자연대, 농대, 약대, 사범대 등 여러 단과대학에서 여러 세대에 걸 쳐 양성한 대학의 경우에는 당연히 많은 인력을 양성하였 다. 기관별 인력양성에서 특이할 사항은 초기에 1 세대 학 자들에 의해 서울의 소수 기관에서 양성되던 석박사가 시 간이 지남에 따라 2 세대 전문인력들에 의해 지방소재의 대 학에서도 많이 양성되고 있는 점이다. 특히 지방소재의 대
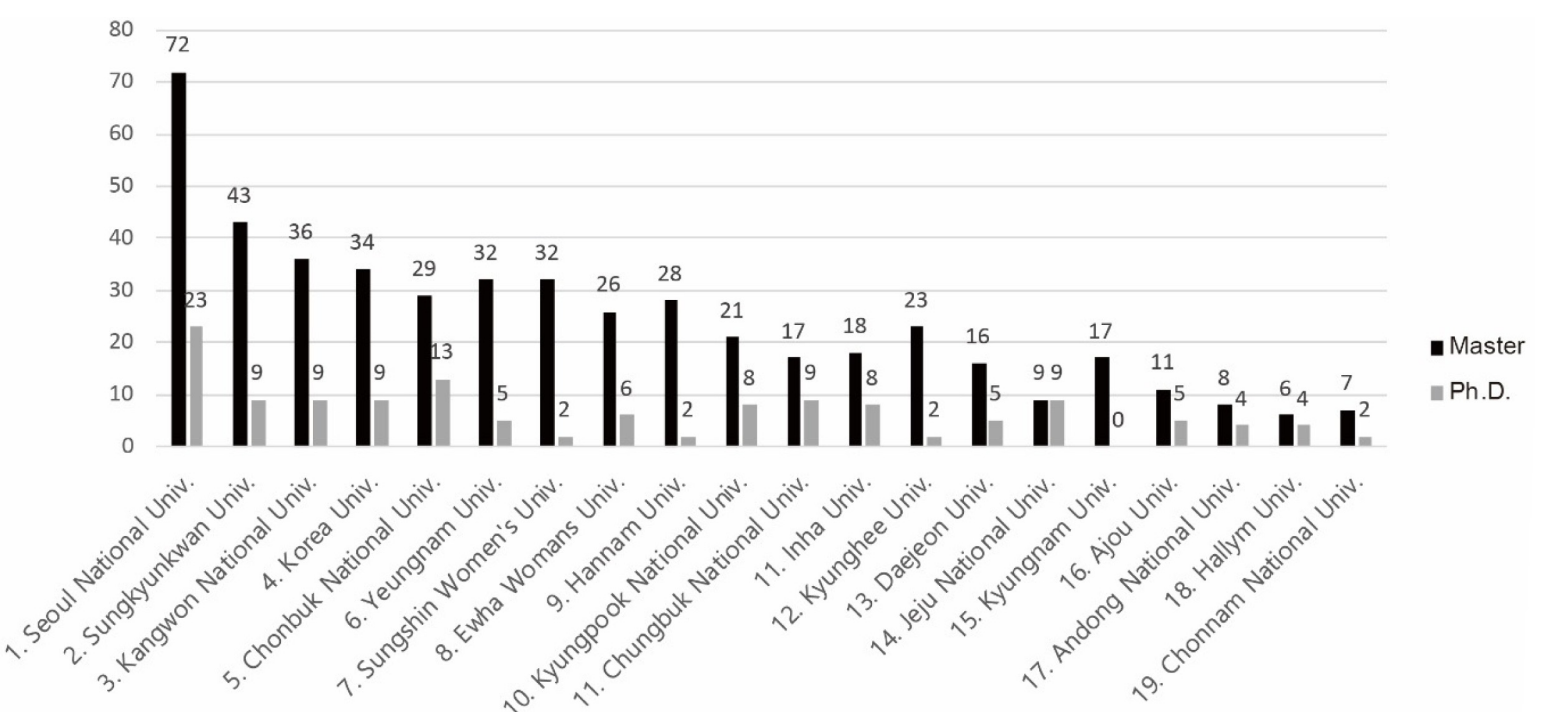

Fig. 3. Number of Masters and Ph.D.s trained in the top 20 institutions. 
학에서 전문인력이 많이 양성되는 것은 자연과 친숙하게 접하는 기회가 많은 점과 관련이 있을 것으로 추정된다.

\section{학회지 발간}

Table 2. Publications issued according to the year during 50 years.

\begin{tabular}{ccc}
\hline \hline Year & Vol. (issues) & Total issues \\
\hline 1969 & Vol. 1 (Issue 1, 2) & 1,2 \\
1970 & Vol. 2 (1, 2 Merged Issue) & 3 \\
1971 & Vol. 3 (1, 2 Merged Issue) & 4 \\
1972 & Vol. 4 (1, 2 Merged Issue) & 5 \\
1973 & Vol. 5 (1, 2 Merged Issue) & 6 \\
1975 & Vol. 6 (1, 2 Merged Issue) & 7 \\
1976 & Vol. 7 (1, 2 Merged Issue) & 8 \\
1978 & Vol. 8 (Supplements) & 9,10 \\
1979 & Vol. 9 (1, 2 Merged Issue) & 11 \\
1980 & Vol. 10 (1, 2 Merged Issue) & 12 \\
1981 & Vol. 11 (1, 2 Merged Issue) & 13 \\
1982 & Vol. 12 (1, 2 Issue) & 14,15 \\
1983 & Vol. 13 (1, 2 Issue) & 16,17 \\
1984 & Vol. 14 (1, 2, 3 Issue) & $18,19,20$ \\
1985 & Vol. 15 (1, 2, 3 Issue) & $21,22,23$ \\
1986 & Vol. 16 (1, 2, 3 Issue) & $24,25,26$ \\
1987 & Vol. 17 (1, 2, 3, 4 Issue) & $27,28,29,30$ \\
$\ldots$ & $(1988-2017$ 4 Issues) & \\
2017 & Vol. 47 (1, 2, 3, 4 Issue) & $147,148,149,150$ \\
\hline & &
\end{tabular}

지난 50년간 2년(1974년과 1977년)을 제외하고는 매년 권당 1, 2, 3, 또는 4호를 발간하였으며, 1987년부터는 매년 4개 호를 발간하여 2017년말까지 총 47권(총 150호)를 발 행하였다(Table 2). 50년간 게재된 총 편수(자료, 보고, 종 설 등 포함)는 1,010 편이며, 1 호에 300 편, 2 호에 239편, 3 호 에 228편, 4호에 243편이었다. 호별 평균 논문 수는 1호부 터 4호까지 각각 6.4, 6.3, 6.7 및 7.8로 4호에 논문 편수가 많 았다. 학회지의 각 권당 논문의 수는 1969-1977년에 5-10 편(평균 6편)이었으며, 1978-1987년에 5-17편(평균 9편) 으로 소수에 불과했지만 1988-1997년에 7-28편(평균 22 편), 1998-2007년에 21-33편(평균 25편), 그리고 20082017년에는 26-52편(평균 40편)으로 증가하였다(Fig. 4). 그러나 $\mathrm{KCI}$ 등재논문에 비해 $\mathrm{SCI}(\mathrm{E})$ 논문이 높이 평가되 는 현실에서 학문적으로 수준 높고 영문으로 작성된 논문 들이 해외학술지로 유출되고 있다. 이는 최근 미기록종 논문 수의 증가와 실험연구논문 수의 감소를 초래하는 경 향이 있어 우려되는 바이다.

\section{연구분야}

학회지 논문에 나타난 연구분야는 식물분류군에 대한 검토 논문이 1988-1997년에 72\%로 가장 많았으나, 19982007년에 68\%, 2008-2017년에 51\%로 감소한 반면, 미기 록종 논문이 각각 1998-2007년에 15\%, 2008-2017년에 $28 \%$ 로 증가되었다(Fig. 5). 긍정적인 측면에서 미기록종 논문의 증가는 지난 2000 년대부터 식물지 사업의 시작으 로 잦아진 야외조사 및 채집활동과 관련이 있을 것이다. 또한 자생식물에 대한 일반인들의 관심이 높아지고 식물 분류학자와의 협업이 꾸준하게 증가한 것과도 관련이 있

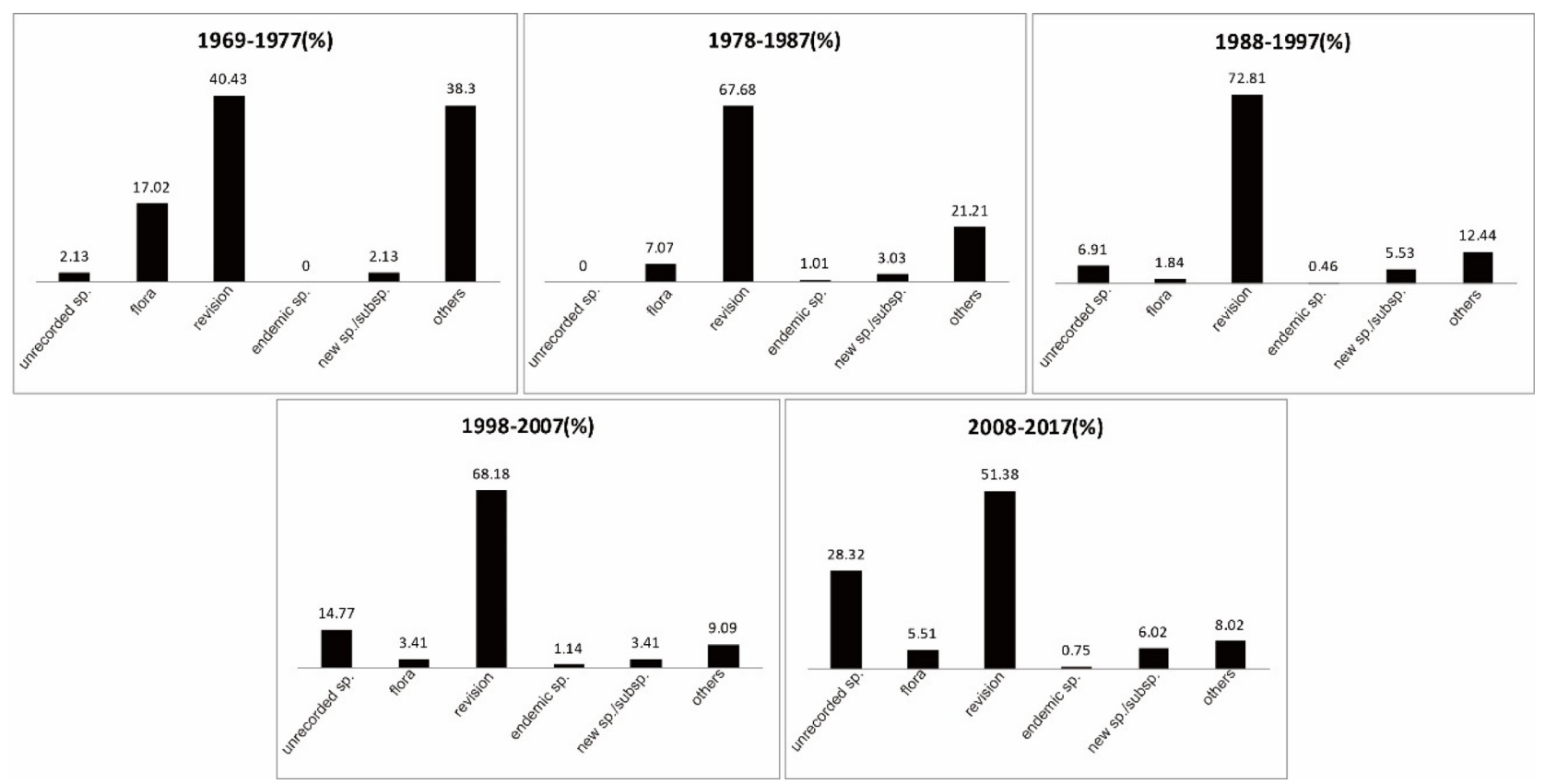

Fig. 4. The number of papers per year and the total number of papers per issue. 


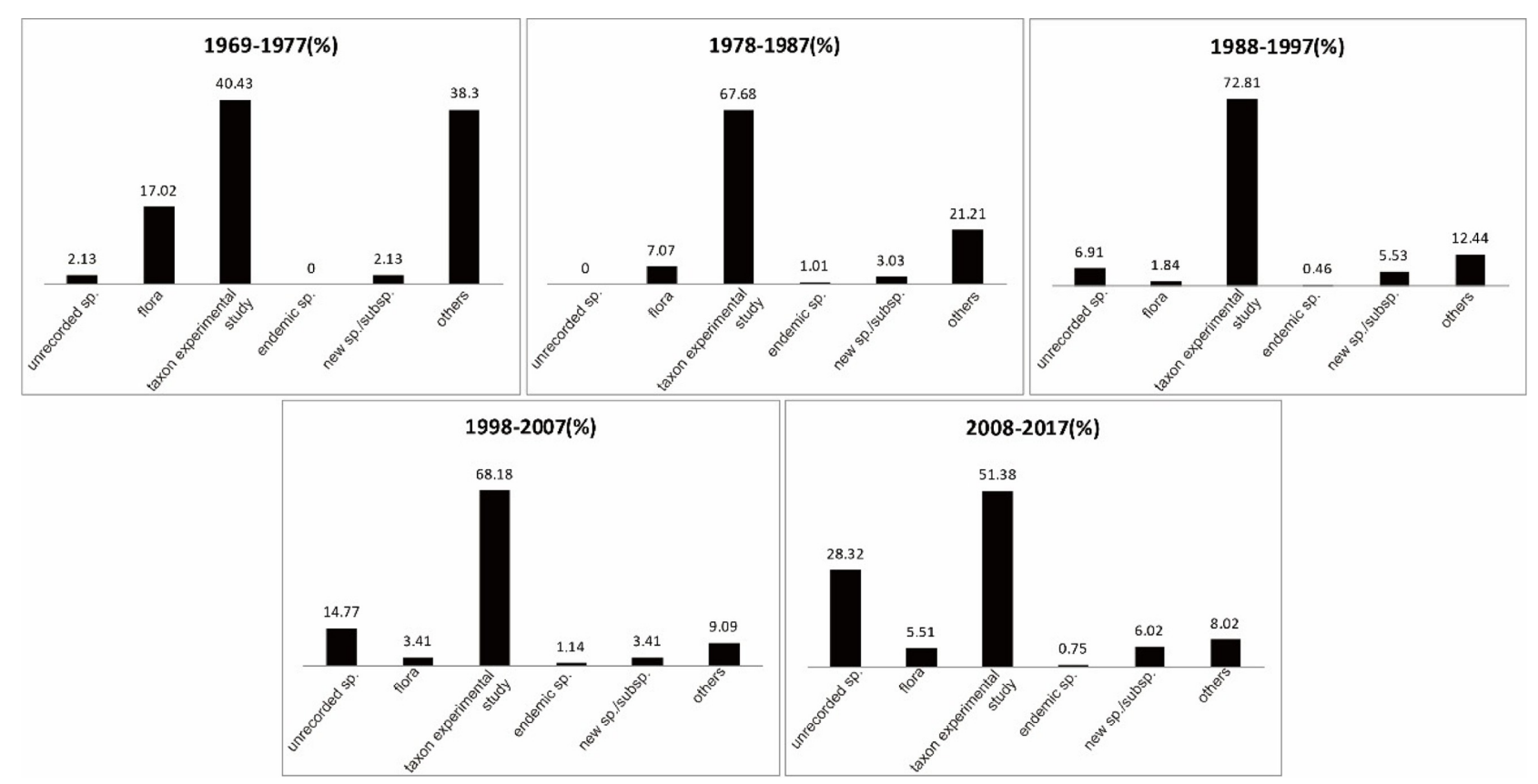

Fig. 5. Changes in research field in decade increments.

papers

350

308 (49\%)

300

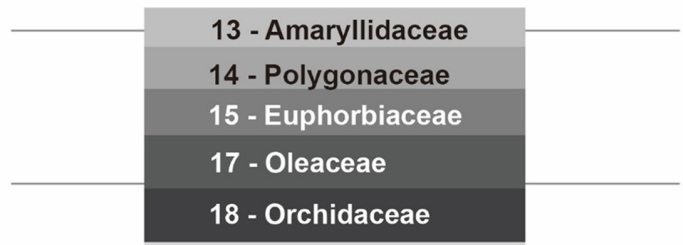

200

18 - Lamiaceae

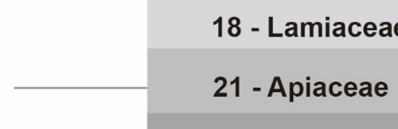

22 - Fabaceae

150

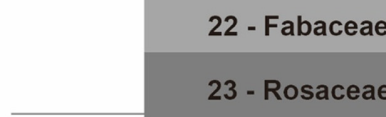

31 - Liliaceae

100

36 - Cyperaceae

\section{6 - Ranunculaceae}

44 - Asteraceae

0

Fig. 6. Major taxa, accounting for $49 \%$ of taxonomic revision papers (629) for 50 years.
고 여겨진다. 이러한 과정에서 비전문인력의 일반회원 자 격제도가 신설되었다. 학회지에 게재된 전체 연구논문들 중 분류군에 대한 검토 논문은 629편이며, 그 분류군 검토 논문들의 $49 \%$ 를 차지하는 308 편 논문의 대상 분류군들은 국화과, 미나리아재비과, 사초과, 백합과, 장미과, 콩과, 미나리과, 꿀풀과, 난과, 물푸레나무과, 대극과, 마디풀과, 수선화과로 나타났다(Fig. 6).

연구방법에 있어서 1969-1977년에는 형태를 바탕으로 한 분류논문이 $6 \%$ 이고 소고 등 기타가 $77 \%$ 이며, 1978 1987 년에는 형태 $23 \%$, 화분 $20 \%$, 기타 $48 \%$ 를 차지했다. $1988-1997$ 년에는 형태 $37 \%$, 화분 $14 \%$, 기타 $38 \%$ 외에 유 전자 연구방법이 4\% 정도로 시작되었다. 1998-2007년에 는 형태 $44 \%$, 기타 $30 \%$, 유전자 $16 \%$ 였다. 최근 연구의 주 류를 이루는 DNA연구논문은 비교적 낮은데 반해 20082017년에는 미기록종 논문의 증가에 따라 형태논문이 $51 \%$ 로 증가하였다(Fig. 7).

국제적 학문교류를 위한 영문논문 발간은 1983년 한일 공동심포지움 이후 추진되어 1985년을 전후하여 영문논 문의 비율이 잠시 향상된 적이 있었으나 그 후 약 20년 동 안 미진한 상태였다. 최근 $\mathrm{SCI}$ 논문의 등재조건을 갖추기 위한 노력으로 2008-2017년 동안 전체 논문들 중에서 영 문논문의 비율은 $43 \%$ 정도로 향상되었다(Fig. 8). 이는 주 로 미기록종 논문에 의해 향상된 것이다. 그 전 시기에는 약 $10-20 \%$ 이었으며, 이는 대부분 국제심포지움 연사들의 발표논문에 의한 것이다.

지난 50년 동안의 자료를 정리하며, 우리 학회가 그 동 안의 수많은 변화와 부침 속에서도 여전히 부족한 점이 

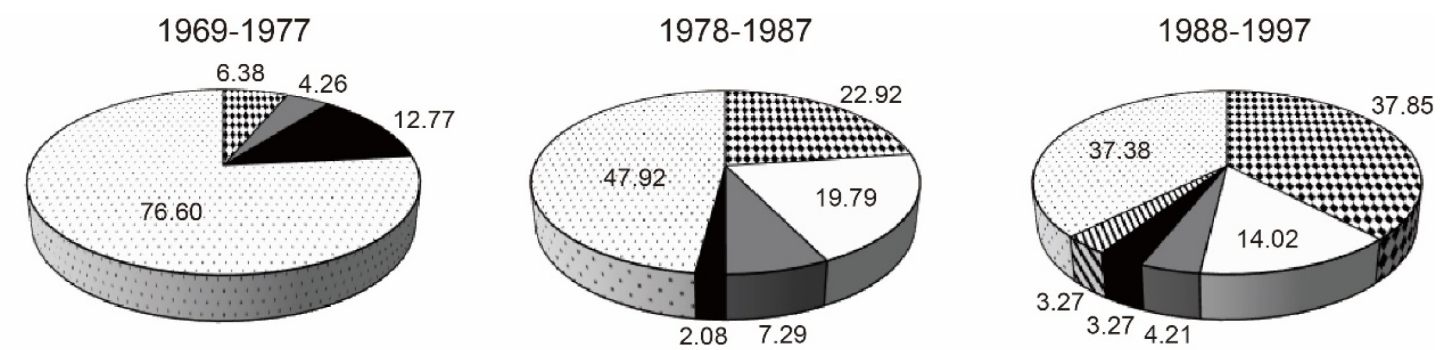

1998-2007
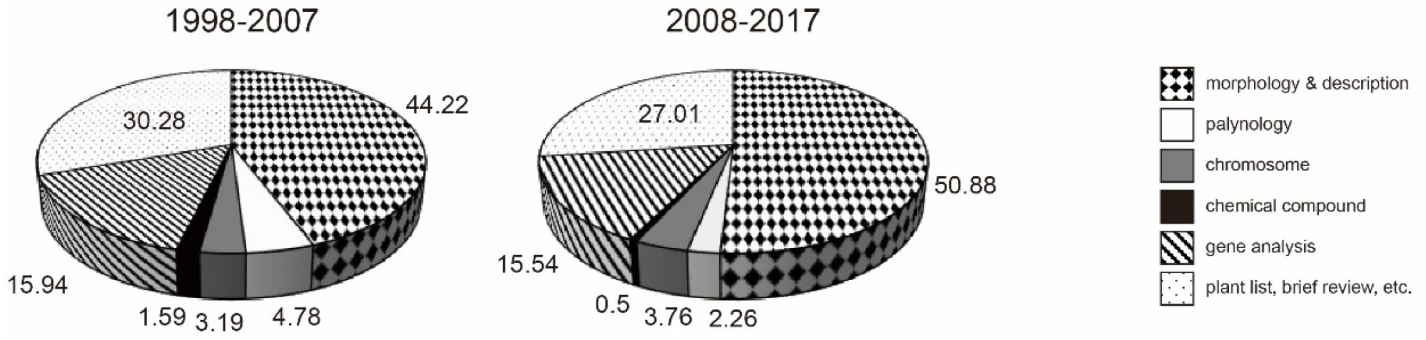

Fig. 7. Changes in research method in decade increments.

$\%$

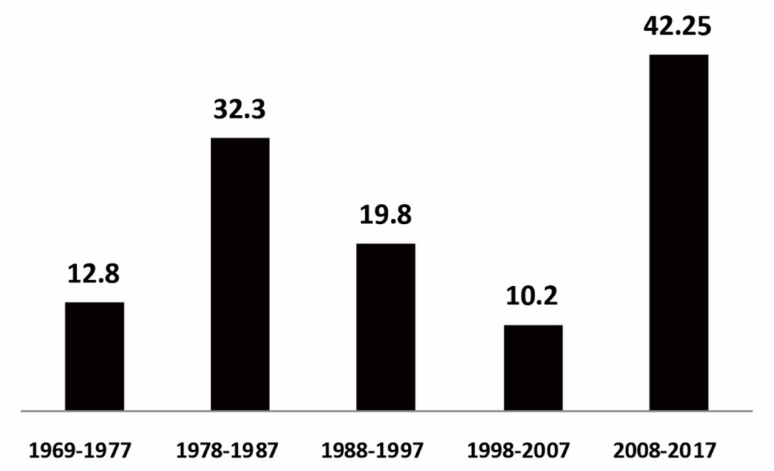

Fig. 8. The ratio of the papers in English among the total number of papers in decade increments.

있으나 전반적으로는 꾸준히 성장해 왔음을 깨닫게 된다. 이제 지난 50 년을 바탕으로 앞으로 50 년을 준비해 나가야 할 출발점이다. 생물자원과 각 국가의 생물주권이 나날이 중요해지는 시점에서 식물분류학자들의 역할은 앞으로 더욱 중요해질 것이라 생각한다. 안으로는 우리 식물에 관 한 심도 있는 연구를 발전시키고 특히 영문논문의 비를 높 여 국제적으로 영향력 있는 학회지로 발전시키고, 밖으로 는 해외식물자원에 대한 연구를 통해 우리 식물종에 대한 보존, 가치제고에 이바지하는 것이 우리의 역할일 것이다.
끝으로 초창기 우리나라 식물분류학을 키워내시고 성장 의 발판을 만들어 주셨던 원로, 선배 연구자들에게 무한한 존경과 감사의 인사를 드리고, 앞으로 한국식물분류학회 를 이끌어 나갈 후배 연구자들에게 응원과 격려를 보내며 한국식물분류학회 50 년사의 정리를 마무리하고자 한다.

\section{Acknowledgments}

This research was supported by the BK21 Plus program (Creative Academy of Eco Science, 31Z20130012990) of the Ministry of Education and the National Research Foundation of Korea (NRF). The author thanks Hyewon Kim of the Eco Creative program at Ewha Woman University, who helped to analyze the data.

\section{Conflict of Interest}

The author declares that there are no conflicts of interest.

\section{Literature Cited}

Korean Journal of Plant Taxonomy. 1969-2017. Journal archive, Vols. 1-47. Retrieved Dec. 1, 2018, available from https:// www.e-kjpt.org/articles/archive.php. 


\section{한국식물분류학회 50 년사: 인력양성과 연구활동 \\ 이남숙* \\ 이화여자대학교 생명과학과}

적 요: 한국식물분류학회가 1968년 12월 13일에 설립된 이래, 전문인력 양성과 학회지 논문에 나타난 연구 활동에 대해 분석하였다. 조사 방법은 한국식물분류학회 홈페이지와 식물분류학회지에 나타난 자료를 이용 하였으며, 전문인력 분석은 각 대학에서 제공한 자료를 바탕으로 하였다. 지난 50 년 동안 식물분류학의 전문 인력은 총 680 명이 양성되었으며, 그 중 석사학위 소지자는 30 개 대학에서 약 537명(남성 274명, 여성 263명) 이고, 박사학위 소지자는 26개 대학에서 143명(남성 97명, 여성 46명)이 양성되었으며, 그 수는 특히 1998년 부터 크게 증가하였다. 연구분야의 변화를 10년 단위로 보면, 분류군 실험논문은 1988-1997년에 $72 \%$ 로 가장 많았으나, 최근 10 년에는 $51 \%$ 로 감소하였다 반면, 미기록종 논문이 $28 \%$ 로 높아졌다. 학회지에 게재된 전체 연구논문들 중 분류군을 검토한 논문이 629 편이며, 그 중 $49 \%$ 를 차지하는 논문의 대상 분류군들은 국화과, 미나리아재비과, 사초과, 백합과, 장미과, 콩과, 미나리과, 꿀풀과, 난과, 물푸레나무과, 대극과, 마디풀과, 수 선화과로 나타났다. 10 년 단위로 연구방법의 변화를 볼 때 형태논문은 $6 \%$ 에서 $51 \%$ 로 증가되었고, 화분논문 은 $20 \%$ 에서 최근에 $2 \%$ 로 낮아졌다. 염색체 연구는 약 3-4\%, 성분연구는 약 $2 \%$ 로 낮고, DNA연구의 비율도 $3-16 \%$ 로 낮았다. 10 년 단위별 전체 논문 수중 영문논문의 비율은 최근에 $43 \%$ 정도로 향상되었는데, 이는 주로 미기록 분류군들의 논문이 증가한 데 기인한다.

주요어: 식물분류학회, 50 년사, 인력양성, 연구분야, 연구방법 